\title{
KOMBINASI KOTORAN AYAM DAN KOTORAN KERBAU YANG DIFERMENTASI TERHADAP PERTUMBUHAN DAN PRODUKSI PADA MAGGOT (Hermetia illucens)
}

\section{Combination of Fermented Chicken Manure and Buffalo Dung on Growth and Production of Maggots (Hermetia illucens)}

\author{
T. Iskandar Johan, Aldi Fahrizal, Fakhrunas M.A. Jabbar \\ Program Studi Budidaya Perairan, Fakultas Pertanian, Univrsitas Islam Riau \\ Email: isjhont@agr.uir.ac.id \\ [Diterima: Oktober 2021; Disetujui: Desember 2021]
}

\begin{abstract}
The purpose of this study was to determine the effect of the combination of chicken manure and buffalo manure on the growth and production of maggot and to determine the percentage of the best combination of chicken manure and buffalo dung on the growth and production of maggot. This study used a completely randomized design with five treatments and three replications, consisting of treatments P1: Chicken Manure (100\%), P2: Buffalo Manure (25\%) + Chicken Manure (75\%), P3: Buffalo Manure (50\%) + Chicken Manure (50\%), P4: Buffalo Manure (75\%) + Chicken Manure (25\%), and P5: Buffalo Manure (100\%). The results showed that the best treatment was found on P2: Buffalo Manure (25\%) + Chicken Manure (75\%) with maggot weight growth of P2 $0.143 \mathrm{~g}$, maggot length growth of $1.49 \mathrm{~cm}$, maggot daily growth rate of $1.02 \%$, and $93.00 \mathrm{gr}$ for maggot production.
\end{abstract}

Keywords: Maggot, Chicken Manure, Buffalo Dung, Fermentation, Growth, Production

\begin{abstract}
ABSTRAK
Tujuan dari penelitian ini adalah untuk mengetahui pengaruh dari kombinasi kotoran ayam dan kotoran kerbau terhadap pertumbuhan dan produksi pada maggot dan mengetahui persentase kombinasi kotoran ayam dan kotoran kerbau yang terbaik terhadap pertumbuhan dan produksi pada maggot. Penelitan ini menggunakan rancangan acak lengkap terdiri dari lima perlakuan dan tiga ulangan terdiri dari perlakuan P1: Kotoran Ayam (100\%), P2: Kotoran Kerbau (25\%) + Kotoran Ayam (75\%), P3: Kotoran Kerbau (50\%) + Kotoran Ayam (50\%), P4: Kotoran Kerbau (75\%) + Kotoran Ayam (25\%) dan P5: Kotoran Kerbau (100\%). Hasil penelitian menunjukkan bahwa perlakuan terbaik terdapat pada P2: Kotoran Kerbau (25\%) + Kotoran Ayam (75\%) dengan pertumbuhan berat maggot, yaitu P2 $0,143 \mathrm{gr}$, pertumbuhan panjang maggot $1,49 \mathrm{~cm}$, laju pertumbuhan harian maggot 1,02\%, dan produksi maggot 93,00 gr.
\end{abstract}

Kata kunci: Maggot, Kotoran ayam, Kotoran kerbau, Fermentasi, Pertumbuhan, Produksi

\section{PENDAHULUAN}

Usaha budidaya perikanan pada saat ini sangat potensial sekali untuk dikembangkan, karena tingkat kebutuhan manusia terhadap ikan setiap harinya semakin meningkat. Hal ini disebabkan karena meningkatnya jumlah populasi manusia dan timbulnya kesadaran terhadap jenis pangan yang bermutu dan berkualitas baik.

Raharjo (2016) mengatakan bahwa maggot merupakan salah satu alternatif pakan yang memenuhi persyaratan sebagai sumber protein dimana kandungan protein kasar cukup tinggi berkisar antara $30-45 \%$.
Murtidjo (2001) menambahkan bahwa bahan makanan yang mengandung protein kasar lebih dari $19 \%$, digolongkan sebagai bahan makanan sumber protein. Selain itu maggot juga memiliki kelebihan yaitu memiliki kandungan anti mikroba dan anti jamur, sehingga tidak membawa agen penyakit. Maggot biasanya dapat dijumpai pada limbah bahan organik karena maggot bekerja mengkonversi limbah organik menjadi biomassa yang lebih sederhana.Maggot juga dapat hidup pada kotoran hewan ternak yang pada dasarnya masih memiliki kandungan nutrisi yang mendukung kehidupan dan pertumbuhannya. Selama ini kotoran hewan 
ternak hanya dianggap sebagai limbah dan diketahui pemanfaatan hanya sebatas dijadikan pupuk bagi tanaman.

Pada kotoran ayam dan kotoran kerbau masih terdapat kandungan protein, karbohidrat, lemak, dan senyawa organik lainnya walaupun tidak tinggi. Murtidjo (2001) kandungan protein pada kotoran ayam sebesar $11 \%$, lemak $1,80 \%$, dan serat kasar $16 \%$. Sedangkan Islamiyati (2014) melaporkan bahwa protein kasar pada kotoran kerbau sebesar 7,96\%, serat kasar 28,63\%, lemak kasar 0,47\%. Oleh karena itu untuk meningkatkan kandungan nutrisi pada kedua kotoran dilakukan proses fermentasi menggunakan EM4. Sehingga senyawa yang kompleks menjadi senyawa yang lebih sederhana dan mudah diserap oleh maggot.

\section{METODE PENELITIAN}

Penelitian ini dilakukan di Balai Benih Ikan (BBI) Fakultas Pertanian Universitas Islam Riau Pekanbaru pada tanggal 20 mei sampai 09 juni 2019. Dengan waktu pengamatan maggot selama 21 Hari.Analisis kandungan protein pada maggot diLaboraturium Fakultas Perikanan dan Kelautan, Universitas Riau.

Alat yang digunaka pada penelitian ini adalah timbangan analitik, timbangan digital, nampan plastik, milimeter blok, thermometer, kertas lakmus, moisture meter, baskom/ ember, stick es krim, jaring halus. Sedangkan bahan yang digunakan adalah pupa maggotsebanyak 250 gram sebagai bakal calon indukan lalat BSF (Black Soldier Fly), Kotoran ayam dan kotoran kerbau sebanyak $10 \mathrm{~kg}$, EM4, gula pasir dan madu.

Rancangan penelitian ini menggunakan Rancangan Acak Lengkap (RAL) dengan perlakuan kombinasi kedua limbah yaitu kotoran ayam dan kotoran kerbau. Pada penelitian ini menggunakan 5 perlakuan dan 3 ulangan, adapun susunan perlakuannya adalah sebagai berikut :

$\mathrm{P} 1=$ Kotoran Ayam (100\%)

$\mathrm{P} 2=$ Kotoran Kerbau (25\%) + Kotoran Ayam $(75 \%)$

P3 $=$ Kotoran Kerbau $(50 \%)+$ Kotoran Ayam $(50 \%)$

P4 = Kotoran Kerbau (75\%) + Kotoran Ayam (25\%)

P5 = Kotoran Kerbau (100\%)

\section{Parameter yang Diamati}

Parameter yang diamati dalam penelitian ini adalah pertumbuhan maggot meliputi berat dan panjang selama 21 hari pemeliharaan, produksi maggot pada hari akhir pemeliharaan, kandungan protein maggot untuk setiap perlakuan, kondisi media tumbuh maggot selama 21 hari masa pemeliharaan.

Pertumbuhan berat dan panjang maggot dapat dihitung menggunakan rumus Syahrizal et al., (2014) yaitu :

$$
\begin{array}{rl|}
\text { Berat: } & \mathbf{B}=\mathbf{B 2}-\mathbf{B 1} \\
\text { Keterangan : } & \\
\text { B } & =\text { Berat Maggot } \\
\text { B1 } & =\text { Berat Awal Maggot } \\
\text { B2 } & =\text { Berat Akhir Maggot }
\end{array}
$$

$$
\begin{aligned}
\text { Panjang: } & \mathbf{L}=\mathbf{L} 2-\mathbf{L} \mathbf{1} \\
\text { Keterangan } & : \\
\mathbf{L} & =\text { Panjang Maggot } \\
\mathbf{L 1} & =\text { Panjang Awal Maggot } \\
\mathbf{L 2} & =\text { Panjang Akhir Maggot }
\end{aligned}
$$

Laju pertumbuhan harian maggot dapat dihitung menggunakan rumus Zonneveld et al., (1991) yaitu :

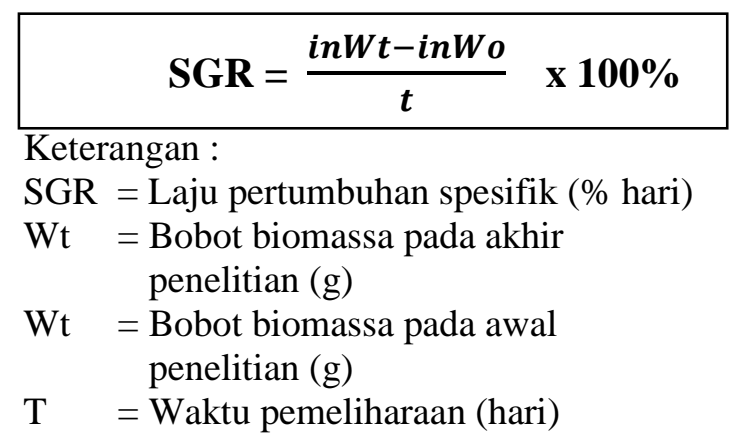

Jumlah produksi maggot dihitung selama 21 hari pemeliharaan dapat diketahui dengan cara melakukan penimbangan hasil total seluruh perlakuan dan ulangan selama penelitian (Syahrizal et al., 2014).

\section{Analisis Data}

Data yang diamati selama dilakukan penelitian ini yaitu pertumbuhan berat dan panjang serta produksi maggot untuk setiap perlakuan dan ulangan. Selanjutnya dilakukan analisis kandungan protein pada maggot dan pengukuran pada media tumbuh maggot yang diperkirakan berpengaruh terhadap penelitian ini. Data yang diperoleh selama penelitian 
disajikan dalam bentuk tabel dan histogram, guna memudahkan dalam menarik kesimpulan.

Data pertumbuhan berat dan panjang serta produksi maggot, sebelum di analisis terlebih dahulu di tabulasikan. Setelah itu dilakukan uji statistik dengan menggunakan ANAVA (Analisis Variansi), apabila terdapat perbedaan yang nyata antara perlakuan atau $\mathrm{F}$ hitung lebih besar dari $F$ tabel maka dilanjutkan dengan uji Beda Nyata Terkecil (BNT).

\section{HASIL DAN PEMBAHASAN}

\section{Pertumbuhan Berat Maggot}

Pertumbuhan berat maggot yang tertinggi terdapat pada pelakuan P2 yang pada hari ke 21 dapat mencapai berat 0,143gr. Sedangkan untuk perrtumbuhan berat maggot yang terendah terdapat pada perlakuan P5 hanya mencapai 0,102 gr. Untuk mempermudah melihat data dapat dilihat pada Gambar 1.

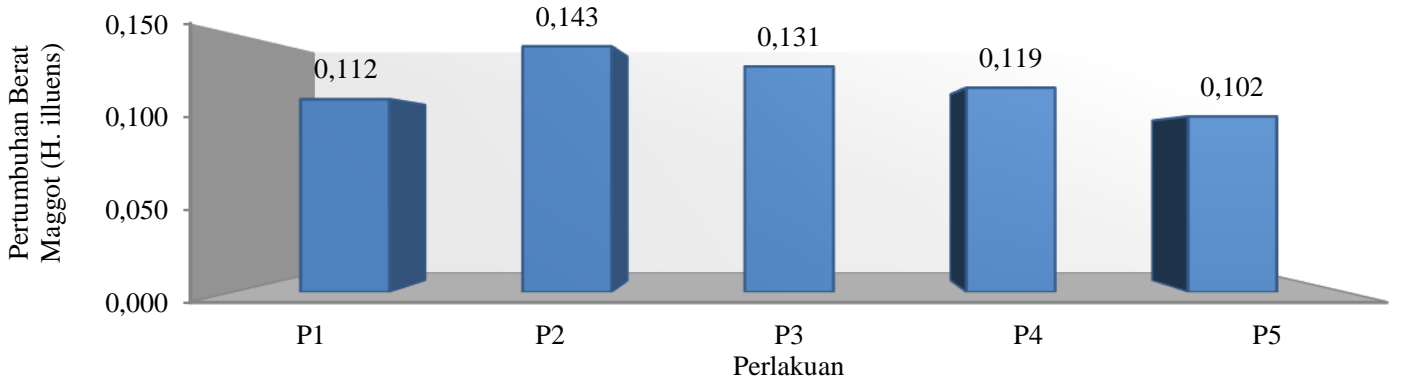

Gambar 1. Grafik Pertumbuhan Berat Maggot.

Pertumbuhan berat maggot tidak lepas dari pengaruh kandungan gizi ataupn nutrisi yang terdapat pada media tumbuh yang diberikan. Perlakuan P4 memberikan hasil yang lebih baik dari perlakuan lainnya, dimana diakhir penelitian berat maggot bisa mecapai 0,143 gr. Tingginya pertumbuhan berat maggot pada perlakuan P2 diduga kandungan gizi yang terdapat pada media tumbuhnya mencukupi dan dapat menunjang pertumbuhan berat maggot. Kombinasi kotoran ayam $75 \%+$ kotoran kerbau $25 \%$ yang terdapat pada perlakuan P2 menghasilkan beberapa kandungan gizi seperti protein, karbohidrat dan lemak yang sangat dibutuhkaan maggot dalam proses pertumbuhannya.

Sesuai pendapat Syahrizal et al., (2014) bahwa maggot dapat tumbuh optimal jika terpenuhnya unsur kebutuhan hidup bagi maggot. Cicilia dan Susila (2018) mengatakan dalam siklus daur hidupnya maggot membutuhkan banyak protein, lemak dan karbohidrat pada saat usia 0-14 hari. Selanjutnya Suciati dan Faruq (2017) menambahkan bahwa secara metabolisme maggot akan mengkonversi protein dan berbagai nutrien yang ada didalam makanannya menjadi biomassa bagi maggot.

Eawag (2017) menyatakan ukuran makanan yang diberikan kepada maggot harus disesuaikan karena maggot yang masih kecil tidak memiliki bagian mulut untuk mengunyah, maka nutrisi akan mudah diserap jika substratnya berupa bagian-bagian kecil atau bahkan dalam bentuk cair atau seperti bubur. Hem et al., (2008) menambahkan pada umumnya subtrat yang bagus akan menghasilkan maggot yang lebih baik pada pertumbuhan dan perkembangan maggot.

\section{Pertumbuhan Panjang Maggot}

Pertumbuhan Panjang tertinggi terdapat pada perlakuan $\mathrm{P} 2$ yaitu $1,49 \mathrm{~cm}$ dan terendah terdapat pada perlakuan P5 yaitu 1,05 $\mathrm{cm}$. Untuk mempermudah melihat pertumbuhan panjang maggot yang dimuat pada Gambar 2.

Pertumbuhan panjang maggot juga dipengaruhi oleh kandungan gizi yang ada di media tumbuh. Pertumbuhan maggot akan baik jika kandungan gizi di media tumbuhnya juga baik. Hal ini dapat dilihat dari pertumbuhan maggot yang tertinggi ada pada perlakuan $\mathrm{P} 2$, dimana pada kombinasi kotoran ayam $75 \%+$ kotoran kerbau 25\% menghasilkan kandungan gizi yang dapat menunjang pertumbuhan panjang pada maggot. Sedangkan pada perlakuan P5 100\% kotoran kerbau diduga pertumbuhan panjang maggot kurang baik karena gizi yang terdapat pada media tumbuh kurang mencukupi sehingga pertumbuhan panjang maggot sedikit terhambat. 


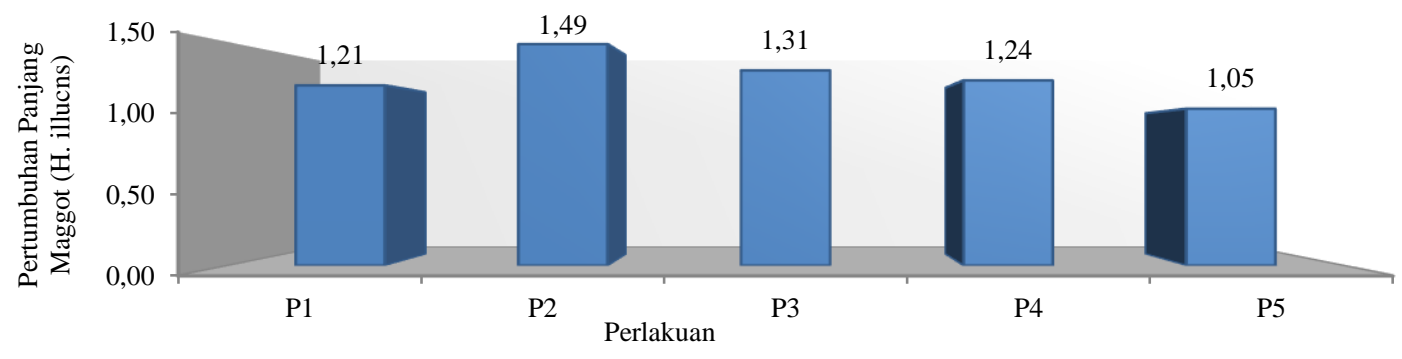

Gambar 4.2. Grafik Pertumbuhan Panjang Maggot.

Menurut De Haas et al., (2006) bahwa kualitas media tumbuh yang baik akan memberikan dampak yang positif terhadap pertumbuhan panjang maggot dan persentase daya tahan hidup lalat dewasa. Kemudian Susanto (2002) keadaan lingkungan atau tempat hidup dan jumlah bahan makan yang tersedia sangat mempengaruhi pertumbuhan setiap organisme. Jumlah makanan yang diperoleh dapat mempengaruhi kecepatan pertumbuhan maggot baik berat maupun panjang. Selain itu Arief et al., (2012) mengatakan bahwa kekurangan energi dapat menghambat perkembangan tubuh maggot.

\section{Laju Pertumbuhan Harian Maggot}

Pertumbuhan harian maggot tertinggi terdapat pada perlakuan P2 yaitu 1,02\% dan terendah perlakuan P5 yaitu $0,73 \%$. Untuk melihat laju pertumbuhan harian maggot dapat dilihat pada Gambar 3.

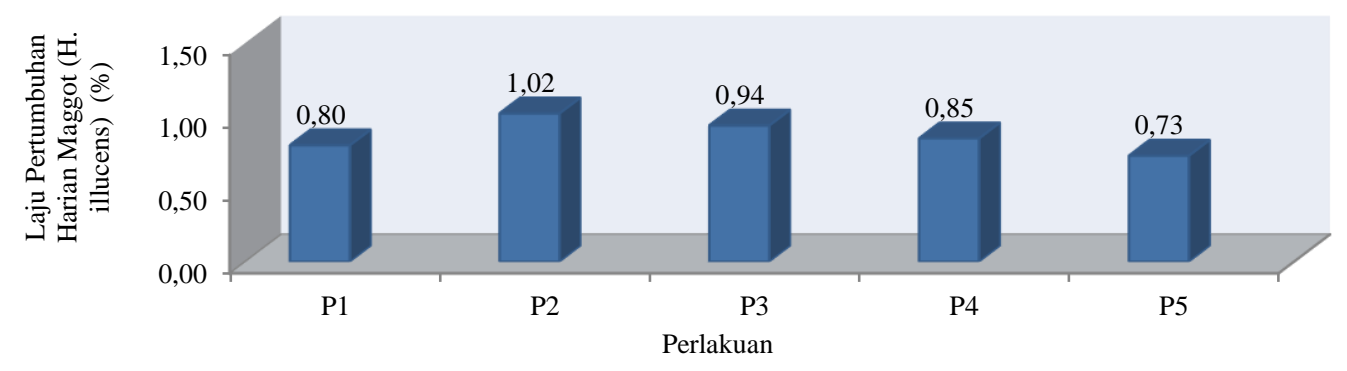

\section{Gambar 4.3. Grafik Laju Pertumbuhan Harian Maggot}

Selama penelitain dan pengamatan, maggot yang terdapat pada perlakuan P2 sedikit lebih aktif jika dibandingkan dengan perlakuan lainnya yang dapat dilihat dari media tumbuh yang terus berkurang dan terurai setiap harinya. Hal ini membuktikan maggot yang terdapat pada perlakuan P2 meyukai media tumbuh yang diberikan yaitu kotoran ayam $75 \%$ + kotoran kerbau $25 \%$. Seperti yang diduga media tumbuh yang terdapat pada perlakuan P2 memiliki kandungan gizi yang cukup baik dan mendukung untuk pertumbuhan maggot, sehingga maggot menyukai dan terus mengkonsumsi media tumbuhnya.

Hal ini sesuai dengan pernyataan Raharjo et al., (2016) maggot menyukai kondisi lingkungan yang lembab dan banyak mengandung nutrien, protein kasar yang terkandung di dalam substrat dan kaya akan bahan organik serta aroma yang khas.
Hastutiek dan Loeki dalam Jayanthi et al., (2017) bahwa selama fase larva, maggot akan terus makan hingga mendekati fase prepupa, selama fase prepupa tidak makan dan akan meninggalkan sumber makanan.

\section{Produksi Maggot}

Hasil produksi maggot yang terdapat padaperlakuan P2 menghasilkan produksi maggot yang tertinggi yaitu 93,00 gr dan perlakuan P5 yang terendah hanya 64,33 gr. Untuk lebih jelasnya dapat dilihat pada Gambar 4.

Produksi maggot tertinggi terdapat pada perlakuan P2 yaitu 93,00 gr. Produksi maggot dipengaruhi oleh berat individu maggot, tingginya produksi maggot yang terdapat pada perlakuan P2 dikarenakan pertumbuhan berat individu maggot juga terdapat pada perlakuan P2. Mangunwardoyo et al., (2011) menambahkan bahwa untuk 
menghasilkan produksi maggot yang tinggi dapat dilakukan dengan cara memberikan media tumbuh yang kaya akan nutrisi, sehingga pertumbuhan dapat meningkat dan produksi berat maggot juga dapat meningkat. Selain itu juga kondisi lingkungan seperti suhu dan kelembapan juga mempengaruhi dari hasil produksi maggot. Suhu akan mempengaruhi daya tetas telur yang digunakan, dimana penelitian ini dilakukan di ruangan semi tertutup sehingga suhu dapat berubah. Kelembapan yang terlalu rendah akan menyebabkan maggot keluar dari media tumbuhnya. Sedangkan jika kelembapan terlalu tinggi menyebabkan maggot diam dan tidak aktif mengkonsumsi makanannya dan berpengaruh terhadap berat tubuh maggot sehingga mempengaruhi hasil produksi.

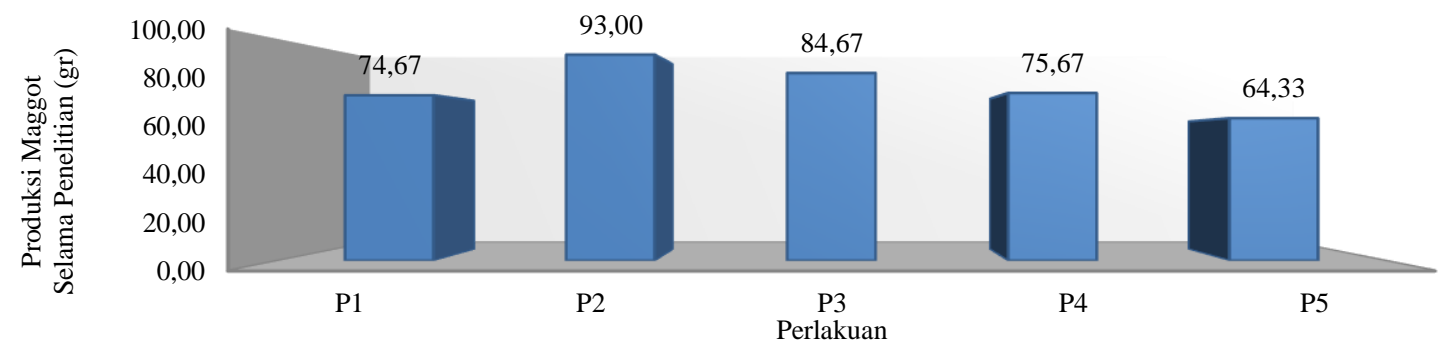

Gambar 4.4. Grafik Hasil Produksi Maggot.

\section{Protein Maggot}

Hari terakhir penelitian dilakukan anlisis kandugan protein maggot, hal ini bertujuan untuk mengetahui apakah media tumbuh yang digunakan bagus dan dapat menghasilkan maggot dengan protein yang baik. Hasil analisis kandungan protein maggot dapat dilihat pada Tabel 1.

Tabel 1. Hasil Analisis Protein Media Tumbuh dan Maggot

\begin{tabular}{ccc}
\hline \multirow{2}{*}{ Perlakuan } & \multicolumn{2}{c}{ Kandungan Protein (\%) } \\
\cline { 2 - 3 } P1 & Media Tumbuh & Maggot \\
P2 & 21,05 & $24,05^{*}$ \\
P3 & 17,79 & 20,36 \\
P4 & 14,53 & 18,74 \\
P5 & 11,26 & 17,68 \\
& 8,00 & $17,34^{*}$ \\
\hline
\end{tabular}

Protein maggot tertinnggi terdapat pada perlakuan P1 yaitu $24,05 \%$ dan yang terendah terdapat pada perlakuan P5 yaitu $17,34 \%$. Hasil ini berbeda dengan hasil yang didapatkan pada pertumbuhan dan produksi, hal ini disebabkan untuk kandungan protein maggot dipengaruhi dari kandungan protein pada media tumbuh dan juga umur maggot itu sendiri. Maggot mempunyai enzim disistem pencernaannya yang mampu mengubah kandungan protein pada media tumbuh menjadi protein pada tubuhnya.

Hal ini sesuai dengan pendapat Sesuai pendapat Katayane et al., (2014) bahwa maggot memanfatkan sumber protein yang terkandungan pada media tumbuhnya untuk membentuk protein pada tubuhnya. Selanjutnya Kim et al., (2011) menambahkan bahwa maggot mampu memakan berbagai jenis bahan orgnik. Selain itu pada sistem pencernaan maggot terdapat enzim protease, lipase dan amylase yang dapat merubah bahan organik menjadi protein, lemak maupun kalori di dalam tubuhnya.

\section{Kondisi Media Tumbuh}

Untuk mendukung penelitian ini selama penelitian berlangsung dilakukan pengukuran parameter kondisi media tumbuh maggot meliputi suhu, $\mathrm{pH}$ dan kelembapan. Hasil pengukuran dapat dilihat pada Tabel 2.

Suhu media tumbuh maggot selama penelitian berlangsung berkiar antara 28 $34^{\circ} \mathrm{C}$. Peningkatan suhu terjadi pada mingggu kedua pengamatan, suhu media meningkat disebakan oleh aktivitas maggot dalam mengkonsumsi makanannya. Dortmans et al., (2017) mengatakan suhu yang ideal untuk media hidup maggot berkisar antara 24 $30^{\circ} \mathrm{C}$. Perubahan suhu yang terjadi diduga selain faktor lingkungan juga dikarenakan oleh aktivitas penguraian yang dilakukan oleh maggot karena kebutuhan nutrisinya terpenuhi.Monita (2017) mengatakan 
perubahan suhu selama proses degradasi sampah organik berhubungan erat dengan aktivitas makan maggot. Selain itu, suhu dan kelembaban udara di sekitar wadah perlakuan juga turut mempengaruhi suhu pengomposan.

Tabel 2. Hasil Pengukuran Kondisi Media Tumbuh Maggot

\begin{tabular}{clc}
\hline No & \multicolumn{1}{c}{ Kondisi Media Tumbuh } & Kisaran Angka \\
\hline 1. & Suhu & $28-34^{\circ} \mathrm{C}$ \\
2. & Kelembapan & $60-75 \%$ \\
3. & pH & $6,7-6,9$ \\
\hline
\end{tabular}

Sumber : Data Primer

Menurut Fahmi (2009) bahwa maggot muda memiliki karakter menyerap air. Kemudian Sipayung (2015) menyatakan bahwa maggot akan optimum mengkonsumsi media pada kelembapan diatas $60 \%$ namun jika terlalu tinggi juga tidak baik. Semakin tinggi kadar air dalam media yang diberikan membuat maggot cenderung untuk keluar dari reaktor pembiakan, mencari tempat yang lebih kering. Namun kurangnya kadar air juga tidak baik karena menghambat proses pencernaan maggot. Monita (2017) Kadar air dalam media tumbuh yang sesuai dapat mendukung aktivitas makan maggot menjadi lebih optimal sehingga pertumbuhannya juga menjadi lebih optimal. Selama proses pengomposan, larva sangat aktif makan sehingga kondisi ini menyebabkan penurunan kadar air pada media.

Pengukuran prameter terakhir yaitu $\mathrm{pH}$ berkisar antara 6,7 - 6,9 yang masih dikategorikan dalam kondisi baik dan normal. Maggot masih dapat hidup dan beradaptasi di media tumbuh dengan kadar $\mathrm{pH}$ yang cukup rendah maupun tinggi. Hal ini sesuai dengan pendapat Monita (2017) bahwa maggot memiliki tingkat toleransi hidup yang cukup tinggi. Maggot sangat toleran terhadap berbagai kondisi lingkungan termasuk $\mathrm{pH}$ media tumbuh yang ekstrim. Adrian dalam Suciati dan Faruq (2017) menambahkan bawah maggot tergolong kebal dan dapat hidup di lingkungan yang cukup ekstrim, seperti di media/sampah yang banyak mengandung garam, alkohol, acids/asam dan amonia. Kemudian Ardiningtyas (2013) mengatakan media atau bahan yang difermentasai menggunakan $\mathrm{EM}_{4}$ biasanya kadar $\mathrm{pH}$ mendekati normal.

\section{KESIMPULAN DAN SARAN}

\section{Kesimpulan}

Berdasarkan hasil dari penelitian yang telah dilakukan dapat ditarik beberapa kesimpulan diantaranya: Pertumbuhan maggot yang meliputi berat, panjang dan laju pertumbuhan harian yang terbaik terdapat pada perlakuan P2 (kotoran ayam $75 \%$ + kotoran kerbau $25 \%$ ) dan yang terendah terdapat pada perlakuan P5 (ampas tebu 100\%), pertumbuhan berat mggot tertinggi yaitu P2 0,143 gr, pertumbuhan panjang maggot tertinggi $\mathrm{P} 21,49 \mathrm{~cm}$, dan laju pertumbuhan harian maggot tertinggi P2 1,02\%, hasil produksi maggot di akhir penelitian tertinggi terdapat pada perlakuan P2 yaitu 93,00 gr dan terendah perlakuan P5 yaitu 64,33 gr, faktor yang mempengaruhi pertumbuhan dan produksi pada maggot diantaranya yaitu kualitas media tumbuh serta kondisi lingkungan hidup maggot seperti suhu, kelembapan dan $\mathrm{pH}$, kandungan protein pada maggot setelah dianalisis mendekati protein yang terkandung di media tumbuh yang diberikan yaitu P1 : 24,05\%, P2 : 20,36\%, P3 : $18,74 \%$, P4 : 17,68\% dan P5 : 17,34\%. Faktor yang mempengaruhi kandungan protein maggot yaitu kualitas media tumbuh dan umurnya dan parameter pengamatan kondisi media tumbuh selama penelitian dalam kategori baik dan mendukung dalam proses pertumbuhan maggot yaitu suhu $28-33^{\circ} \mathrm{C}, \mathrm{pH}$ berkisar antara 6,7-6,9 dan kelembapan 60$75 \%$.

\section{Saran}

Saran yang ingin disampaikan penulis yaitu maggot merupakan salah satu pakan yang baik untuk ikan budidaya, karena dapat diberikan secara langsung dalam bentuk segar dan juga diolah lagi menjadi bahan baku pakan buatan. Jika ingin menggunakan kombinasi kotoran ayam dan kotoran kerbau sebagai media tumbuh maggot, sebaiknya menggunakan kombinasi kotoran ayam $75 \%+$ kotoran kerbau $25 \%$ yang dapat dipanen sebelum hari ke-21. Namun perlu juga dilakukan penelitian lanjutan dengan menggunakan media tumbuh lainnya yang dapat menghasilkan pertumbuhan maggot lebih cepat dan produksinya lebih banyak lagi, serta 
penelitian pengaplikasian maggot ke ikan budidaya.

\section{DAFTAR PUSTAKA}

Ardiningtyas, T. R. 2013. Pengaruh PenggunaanEffective

Microorganisme4 (EM4)dan Molase Terhadap Kualitas Kompos Dalam Pengomposan Sampah Organik RSUD Dr. R. Soetrasno Rembang. Skripsi. Jurusan kesehatan ilmu masyarakat, fakultas ilmu keolahragaan, universitas negeri semarang. Semarang. 109 Halaman.

Arief. M, Ratika. N. A, dan Lamid. M. 2012. Pengaruh Kombinasi Media Bungkil Kelapa Sawit dan Dedak Padi yang difermentasi terhadap Produksi Maggot Black Soldier Fly (Hermetia illucens) sebagai Sumber Protein Pakan Ikan. Jurnal Ilmiah Perikanan dan Kelautan. Vol 4 (1).

De Haas EM, Wagner C, Koelmans AA, Kraak MHS, Admiraal W. 2006. Habitat selection by chironomid larvae: Fast Growth Requires Fast Food. J Anim Ecol. 75:148-155.

Dortmans, B. M. A., S. Diener., B. M. Verstappen dan C. Zurbrugg. 2017. Black Soldier Fly Biowaste Processing - A Step-by-Step Guide. Eawag-Swiss Federal Institute of Aquatic Science and Technology department of Sanitation, Water and Solid Waste for Development (Sandec). Dübendorf, Switzerland. 100 Halaman.

Eawag. 2017. Proses Pengolahan Sampah Organik dengan Black Soldier Fly (BSF). Swiss Federal Institute of Aquatic Science and Technology. 87 P.

Fahmi, M. R., S. Hem dan I. W. Subamia. 2009. Potensi maggot untuk peningkatan pertumbuhan dan status kesehatan ikan. Jurnal Riset Akuakultur. Vol 4 (2) : 221-232.

Hem S, Toure S, Sagbla C, Legendre M. 2008. Bioconversion of palm kernel meal for aquaculture: Experiences from the forest region (Republic of Guinea). African J Biotechnol. Vol 7(8): 11921198.

Jayanthi, R., Khairani, Herika, Muhammad A. dan Rafiqah. 2017. Teknik Budidaya
Black Soldier Fly (Hermetia illucens). Jurnal Jeumpa FKIP Universitas Samudra. Vol.4.(1) : 58-66.

Katayane, F.A., B. Bagau., F.R. Wolayan., dan M. R. Imbar. 2014. Produksi Dan Kandungan Protein Maggot (Hermetia illucens) Dengan Menggunakan Media Tumbuh Berbeda. Jurnal Zootek. Vol 34 (edisi khusus) : 27-36.

Kim, W., Bae, S., Park, K., Lee, S., Choi,W., Han, S., Koh, Y., 2011. Biochemical Characterization Of Digestive Enzymes In The BlackSoldier Fly, Hermetia illucens (Diptera: Stratiomyidae). Journal Of Asia Pasific Entomology. Vol 14.

Mangunwardoyo, W., Aulia., dan S. Hem. 2011. Penggunaan Bungkil Inti Kelapa Sawit Hasil Biokonversi sebagai Substrat Pertumbuhan Larva Hermetia illucens L (Maggot). Biota. Vol 16 (2) : 166-172.

Monita, L., S.H., Sutjahjob, A.A., Aminc dan M.R., Fahmi. 2017. Pengolahan Sampah Organik Perkotaan Menggunakan Larva Black Soldier Fly (Hermetia illucens). Jurnal Pengelolaan Sumberdaya Alam dan Lingkungan. Vol. 7 (3) : 227-234.

Murtidjo, B. A. 2001. Pedoman Meramu Pakan Ikan. Kanisius. Yogyakarta.

Raharjo, E. I., Rachimi., A. Muhamad. 2016. Pengaruh Kombinasi Media Ampas Kelapa Sawit dan Dedak Padi Terhadap Produksi Maggot (Hermetia illucens). Jurnal Ruaya. Vol 4 (2) : 4146.

Sipayung, P. Y. E. 2015. Pemanfaatan Larva Black Soldier Fly (Hermetia Illucens) Sebagai Salah SatuTeknologi Reduksi SampahDi Daerah Perkotaan. Skripsi. Jurusan Teknik Lingkungan, Institut Teknologi Sepuluh November. 130 Halaman.

Suciati, R., dan H. Faruq. 2017. Efektifitas Media Pertumbuhan Maggot Hermetia illucens (Lalat Tentara Hitam) Sebagai Solusi Pemanfaatan Sampah Organik. Biofer, J. Bio. \& Pend. Bio. Vol 2 (1) : 8-13.

Susanto, 2002. Pupuk dan Pemupukan. Penerbit Rineka Cipta. Jakarta. 
Syahrizal., Ediwarman dan M. Ridwan. 2014. Kombinasi Limbah Kelapa Sawit dan Ampas Tahu Sebagai Media Budidaya Maggot (Hermetia illucens) Salah Satu Alternatip Pakan Ikan. Jurnal Ilmiah Universitas Batanghari Jambi. Vol 14 (4) : 108-113.
Zonneveld N, E. A. Huisman dan J.H. Boon. 1991. Prinsip-Prinsip Budidaya Ikan. PT Gramedia Pustaka Utama. Jakarta. 318 halaman. 